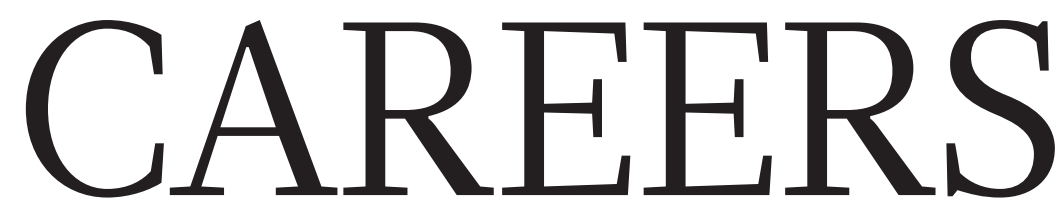

CRIME BUSTER A molecular biologist helps detectives to solve crimes $\mathbf{p . 3 6 3}$

BLOG Personal stories and careers counsel blogs.nature.com/naturejobs
NATUREJOBS For the latest career listings and advice www.naturejobs.com

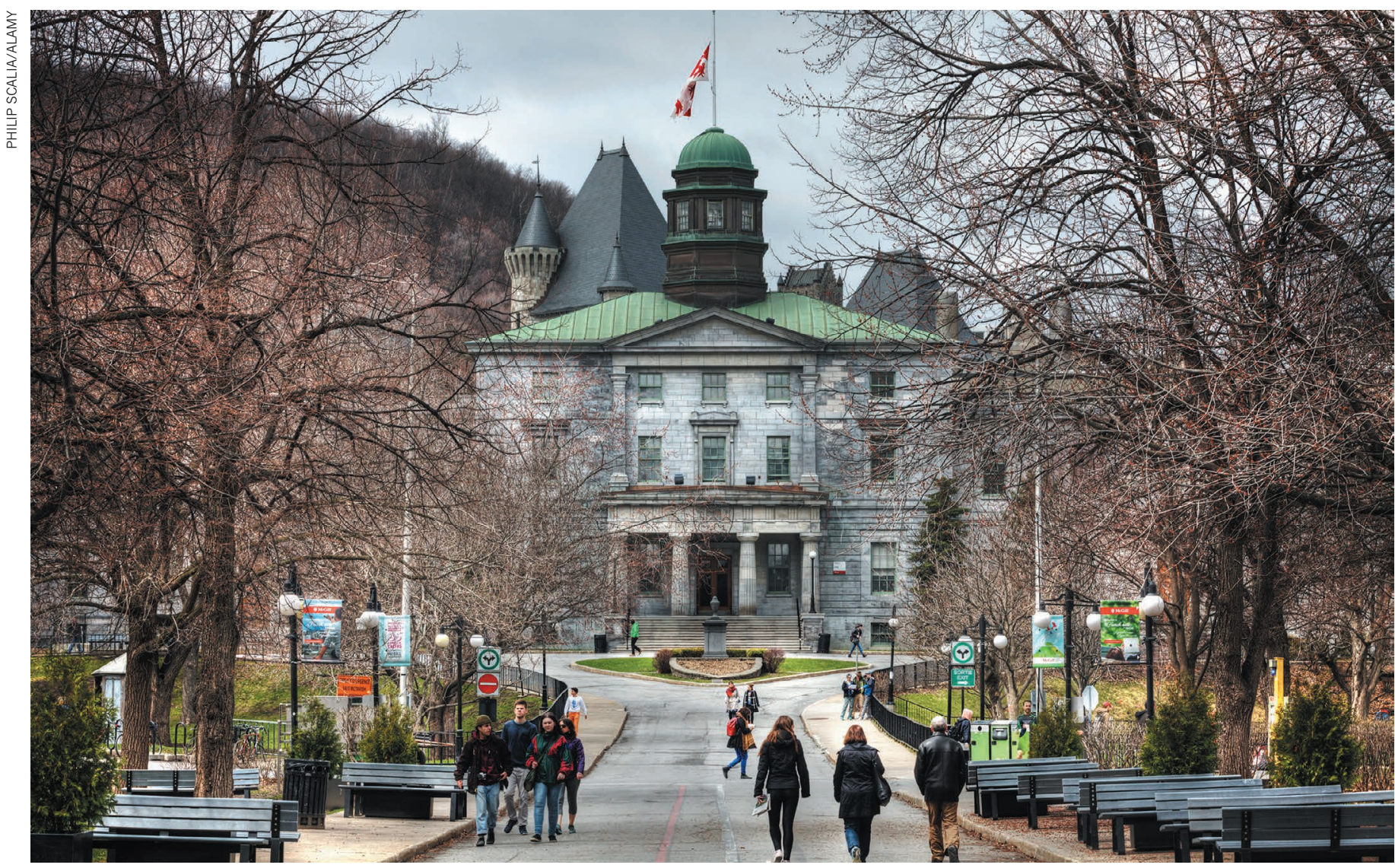

McGill University in Montreal, Canada, is one of many institutions in the country that are capitalizing on the opportunity to attract international students.

\title{
The gamble of going abroad
}

\section{Political concerns and visa access are swaying students deciding where to pursue a degree.}

\section{BY VIRGINIA GEWIN}

S arah Mostafavi's graduate studies got back on track in June, when she was finally able to return to her US master's programme in industrial engineering after experiencing extensive immigration delays.

Mostafavi, who studies at the Virginia Polytechnic Institute and State University in Blacksburg, had travelled home to Iran late last year to receive treatment for back pain. On 19 January, she received notice from US embassy officials in Dubai - Iran has no US embassy - that her visa to return to the United States at the end of January had been approved. But on 27 January, US President Donald Trump issued an executive order that temporarily banned citizens of Iran and six other nations in the Middle East from entering the United States. Mostafavi received her passport back on 31 January - with no visa stamp. Without it, she couldn't return to Virginia.

In the ensuing five-month period, during which US courts overturned and later reinstated a limited version of the ban, Mostafavi had to start her visa-application process anew, which required her to be interviewed in Dubai. Her project deadlines slipped, and she missed a chance for an important professional internship. The ban's status continues to flip-flop. As this issue of Nature went to press, refugees and other individuals from six Muslim-majority countries - Iran, Somalia, Sudan, Syria, Yemen and Libya - could travel to the United States if they have a bona-fide relationship with family or an institution or organization there. The US Supreme Court will review the ban in October.

Universities in the United Kingdom are also facing uncertainties, owing in part to the June 2016 Brexit referendum, in which the nation voted to leave the European Union. Given early indicators suggesting a drop in US and UK enrolments this year, it is tempting to deduce that anti-immigrant rhetoric and shifting visa policies may have deterred international 
students from choosing universities in either nation. But more-inviting visa and citizenship-pathway policies in countries such as Canada and Australia may also have been quietly shaping flows for several years. Ireland, too, is stepping up its international-student recruitment, by extending to two years the length of time that new advanced-degree holders can stay in the nation to seek employment.

In the United States, the travel ban has exacerbated long-standing immigration obstacles for researchers (see Nature 460, 131-132; 2009). "The visa-application process has already been very challenging," says Mostafavi's adviser, industrial engineer Navid Ghaffarzadegan, a fellow Iranian who analyses policy issues such as scientific-workforce development. He points to an increasingly unwelcoming culture that arises from a lack of communication and shared understanding of different backgrounds. This perceived unfriendliness, he says, makes students worry about applying to institutions in a country where they fear they won't be welcomed or for which their visa application may be rejected. "These are risks that many students simply don't want to take," he says.

Ghaffarzadegan - who has a US green card, which grants permanent-resident status to non-US citizens - has seen the ban's effects in his own laboratory. He supervises 8-10 graduate students, many of whom come from foreign countries, including Iran, China, India and Colombia. In the past months, he says, one prospective Iranian student, citing visa concerns, opted for a European university. Another admitted Iranian student finally received her visa after more than three months.

Since at least the 1970s, the United States and the United Kingdom have been the world's top two host nations for international students, followed largely by Australia and France. In 201516, the United States hosted nearly 384,000 international graduate students, and the United Kingdom had about 200,000. But that status may be slipping: early figures suggest that US and UK numbers are dropping, whereas universities in Canada and Australia are reporting spikes in their preliminary application numbers.

Many universities are scrambling to maintain overseas-student numbers, thanks to the desirable scientific expertise and economic contributions of this group. At the same time, students around the world are trying to minimize risk to their future career prospects, says Jill Welch, deputy executive director for public policy at NAFSA: Association of International Educators in Washington DC.

Some US and UK universities have been closely monitoring student interest since last autumn. A joint survey conducted in February by five non-profit US higher-education groups found that $38 \%$ of US universities reported declines in international-graduate-student applications - notably, decreases of 15\%, 31\% and $32 \%$ from India, the Middle East and China, respectively ${ }^{1}$. However, $35 \%$ of US universities

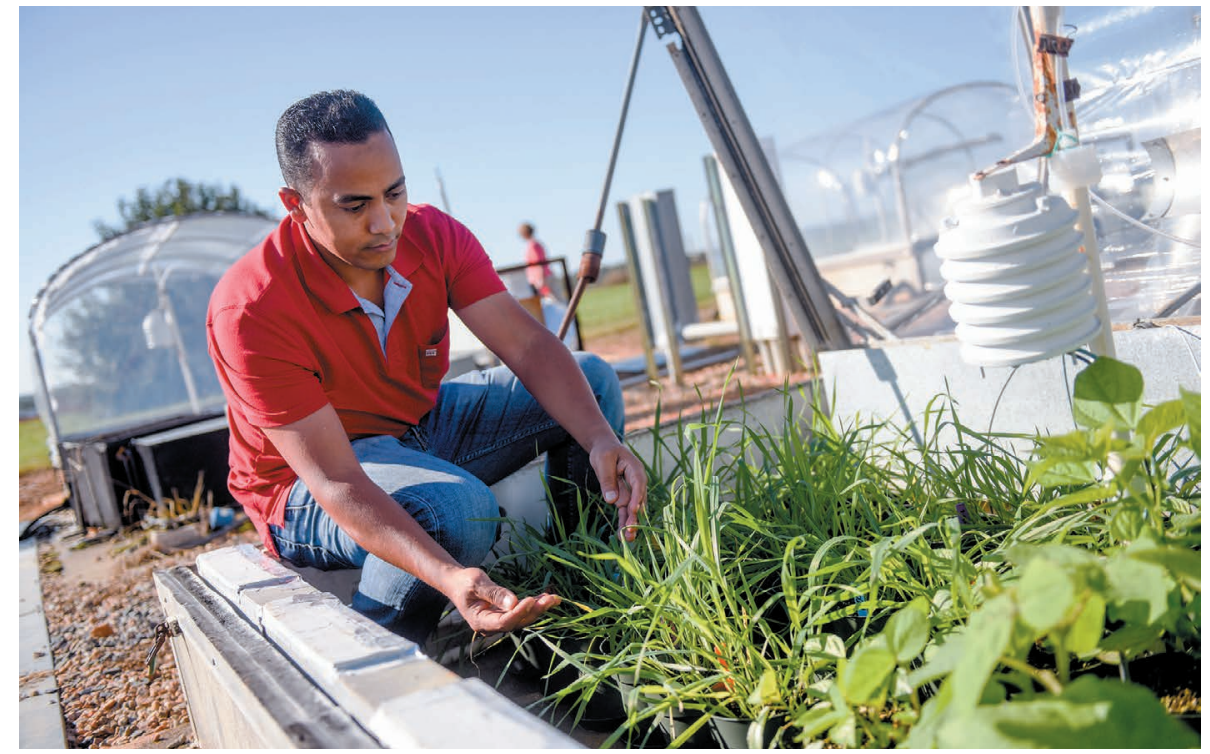

Sayed Mashaheet travelled from Egypt to study crop science at North Carolina State University in Raleigh.

reported increases, which may reflect concerted efforts to attract talent from abroad.

A subsequent survey conducted in July by the same group identified similar trends in student acceptance rates ${ }^{2}$. Almost one-third (31\%) of 176 graduate deans reported a decline of at least $2 \%$ in the number of international $\mathrm{PhD}$ students who had accepted offers compared with 2016. Of research-heavy universities, $27 \%$ reported a decline in acceptance rates compared with 2016, and $33 \%$ reported an increase.

Similar hints appear across the pond. The Russell Group, an association of 24 top UK research-intensive universities, notes a slight decline in application totals from EU citizens for 2017 compared with 2016. And a month after the Brexit vote, Hobsons Solutions, a Londonbased consultancy for universities, conducted a survey of prospective international students ${ }^{3}$. About one-third said that they were less likely to apply to a UK institution given the Brexit vote.

\section{DAMAGE CONTROL}

Last autumn, concerned about political rhetoric, some US universities increased their outreach efforts before and after the election, in an effort to combat perceptions that the nation did not welcome foreign students. Maureen Grasso, dean of the graduate school at North Carolina State University (NCSU) in Raleigh, says that early international-application numbers last autumn suggested a $20 \%$ decline from 2015 totals. The decline was of huge concern to a science-focused institution with 8,500 graduate students, 2,600 of whom are international and bring the diverse academic talent that is necessary for cutting-edge research. The university has posted testimonials on its website from current international students, and it created nation-specific web pages to answer common questions. "It was a tripling of our efforts," says Grasso. The final student yield will be unknown until students are actually in classrooms, because some are still waiting for visas.

Welch says that some US universities offer free summer housing and pro bono legalcounselling services to international students to offset concerns about travel to - and back from - a nation covered by the ban. Others are boosting their outreach efforts in person. Wim Wiewel, president of Portland State University in Oregon, travelled to India earlier this year to talk to parents and current and prospective students about US visa concerns and other issues, including violence against Indian nationals in the United States. "We have spent far more time making sure that people we admitted actually come," says Wiewel.

Many international students see the United States as a riskier investment since the election, says Sayed Mashaheet, a native of Egypt who earned his $\mathrm{PhD}$ in crop science at NCSU, where he is now a postdoc. Many of them travel on studentships from their home government, and so cannot afford delays from immigration obstacles such as those invoked by the travel ban, he says. "They have a limited time to start their programme," says Mashaheet, who is in a Facebook group of 11,000 Egyptian nationals who crowdsource information about the social dynamics and application processes at universities worldwide. Visas and immigration are the principal concerns of Egyptian students with national scholarships, he says, whereas those seeking scholarships abroad are most concerned about postgraduate work availability, citizenship pathways and a welcoming environment.

Some UK groups are also trying to quell concerns. Last year, Universities UK in London, an organization that represents the nation's higher-education institutions, launched a social-media campaign under the tag \#WeAreInternational to reassure international students that universities value them. The association is also calling on the UK government to simplify visa policies and to invest in international 
outreach, as well as in partnerships, to bolster international-student mobility. "The biggest misconception is that the UK is not as welcoming as it once was," says Anthony Manning, dean for internationalization at the University of Kent, UK.

Some predict that a drop in the value of the pound after the Brexit vote could even boost the number of applications to UK institutions from students outside Europe. "The biggest driver of non-EU student interest is that the pound is so much weaker, they can benefit from a UK education at a much more affordable price," says Paul Raybould, marketing director for Hobsons. But that would happen only if the United Kingdom presents itself as welcoming to immigrants, he adds.

\section{TRADING PLACES}

Universities in Canada and Australia are capitalizing on the fallout, as they watch their international-application rates climb. Institutions in both nations have striven for the past several years to maintain their image as premier choices for international graduate students, touting their open immigration policies, easy access to work permits and friendly citizenship pathways.

The strategy seems to be succeeding. In 2016, Australia hosted almost 145,000 international graduate students - an increase of $31 \%$ over 2014 numbers. Enrolment of students in science, technology, engineering and mathematics grew at even higher rates, including those in engineering (48\%), health (42\%) and information technology (40\%), over that two-year period, according to Christopher Ziguras, president of the International Education Association of Australia and international deputy dean for RMIT University in Melbourne, where he also does research on international studies. "It's no accident we're seeing rapid growth here now," says Ziguras. Under Australia's student-visa policy, adopted in 2011, master's and $\mathrm{PhD}$ students can stay in the country for three and four years, respectively, after graduation. "Compared with tightening processes in the US and UK, it's relatively easy for doctoral graduates to obtain permanent residency in Australia," says Ziguras.

Canada has also worked to draw international graduate students, who numbered about 44,000 at the last count, according to Universities Canada. Providing a pathway to citizenship makes Canada an attractive option, notes Leah Nord, director of stakeholder relations at the Canadian Bureau for International Education in Ottawa. For example, Nord says, $20-27 \%$ of international students since the 1990s became permanent residents in the 10 years after their first study permit was issued. Last November, the nation adopted policies to further ease international students' pathway to citizenship.

Sofía Solar Cafaggi from Mexico hopes to

benefit from the nation's open-arms practices. She earned a bachelor's degree in chemical engineering from McGill University in Montreal, Canada, in 2012, and a joint master's in translational medicine from the University of California (UC), Berkeley, and UC San Francisco in 2014. For medical school, she had a choice of attending the Cleveland Clinic in Ohio at no charge, or to pay her own way at the University of Toronto. She opted for Toronto, despite the cost, because she will be eligible for Canadian citizenship after three years. "In the US, I would have stayed an alien for at least the next decade, and that made me nervous about career prospects given the current political drama," she says. "In Canada, at the end of the four-year programme, I should be a citizen. To me, that made a world of difference."

For similar reasons, French national Marius Poyard chose Canada's University of Sherbrooke for a master's programme in mechanical engineering, rather than his US options - Michigan State University in East Lansing or Manhattan College in Riverdale, New York. The Canadian university is much less expensive, he says, and came with no immigration obstacles. "The lower cost and ease of the visa procedure in Canada were the big factors I considered," he says. "And I prefer to be in a more welcoming country."

The University of Toronto is benefiting from its own and the nation's open-door policy: it received $27 \%$ more international-

\section{"In the US, I would have stayed an alien for at least the next decade, and that made me nervous."} student applications for 2017 for a total of 15,000 , compared with 11,951 in 2016. Although the largest increases came from India and nations in the Middle East, applications from US students rose $26 \%$ during that period. "It is all a boon," says Ted Sargent, the university's vice-president for international affairs.

But if the shift continues, it could prove disastrous for UK and US institutions financially and in terms of intellectual capacity. "If they stop coming," says Anita Gopal, international officer for the US National Postdoctoral Association in Rockville, Maryland, "some programmes will simply collapse."

Virginia Gewin is a freelance writer in Portland, Oregon.

1. AACRAO. Trending Topics Survey: International Applicants for Fall 2017- Institutional \& Applicant Perceptions (AACRAO, 2017); available at go.nature.com/2hkqwj3

2. Farrugia, C. \& Andrejko, N. Shifting Tides? Understanding International Student Yield for Fall 2017 (IIE Center for Academic Mobility Research and Impact, 2017); available at go.nature. com/2wx5yos

3. Hobsons Solutions. UK International Student Survey 2017: Welcoming the World (Hobsons, 2017); available at go.nature.com/2vmey44
TRADE TALK Crime buster

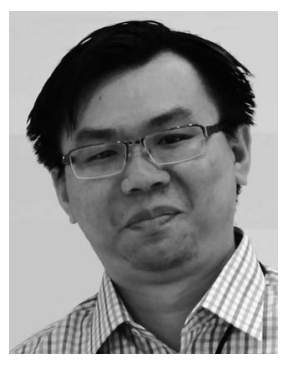

As a PhD student, Kevin Chong studied microorganisms in Antarctica. Now, he's a forensic scientist at the DNA Profiling Laboratory, part of the Singaporean government's Health Sciences Authority, where he helps

investigators to solve crimes.

\section{What do forensic scientists do?}

It's similar to what is portrayed in the US TV series CSI: Crime Scene Investigation. Forensics is the application of science in the legal arena, and a forensic scientist in the biological sciences examines crime-scene evidence for biological fluids, such as blood or semen, and tries to obtain a DNA profile from them.

\section{What happens next?}

We match the profiles to those of convicted offenders in our database. This does not mean that a given person is the suspect - they could be the victim, or unrelated to the case. Lawenforcement agencies determine involvement.

\section{Did you plan to go into forensic science?}

No. When I was an undergraduate student, my research supervisors had $\mathrm{PhDs}$, which influenced me to follow their paths. So I applied to labs that were working on projects that fascinated me, such as on microorganisms that thrive in harsh environments.

\section{Why did you leave academia?}

Pushing the boundaries in science often requires serendipity and time - which can be fleeting in a pressure-cooker environment focused on producing paper-worthy results.

\section{How does your lab differ from academia?}

The focus is on quality assurance. In academia, there are quality controls in every experiment. But we go beyond that here. Our lab's staff members have to be proficiency-tested annually to ensure that we can perform tests to produce a reliable result. Analysts have to review all forensic work and tests. And you can't use expired chemicals. That was a shock - in my PhD lab, no one cared about expiry dates.

\section{What have you learnt in this job?}

Science and those practising it should be neutral. We want the evidence to speak for itself.

This interview has been edited for length and clarity. 